2019 (112): 29-36.

(C) A szerző(k) 2019

replika.hu/replika/112

\title{
Weıss János
}

\section{Csoport és individualızáció}

Georg Sımmel halálának századık éufordulójára

\begin{abstract}
Absztrakt: Az írásom Simmel A társadalmi differenciálódásról címü, 1890-ben megjelent korai fóműve alapján próbálja rekonstruálni a modernitás egyik legkorábbi elméletét. Ez az elmélet ugyanakkor már kritikai reakciónak tekinthető Tönnies Közösség és társadalom címü müvére. Elemzéseimben megpróbálom felmutatni Simmel koncepciójában az adornói-horkheimeri „felvilágosodásdialektika” megelőlegezését. is. De Simmel elméletének aktualitása ezen messze túlmutat: (1) nála lehet először látni, hogy a modernitás elmélete sajátos feszültségben áll a társadalom szerkezetének leírásával, (2) Simmel volt az első, aki az ,idegennek” konstitutív elméleti jelentőséget tudott adni.
\end{abstract}

Kulcsszavak: Simmel, társadalmi differenciálódás, felvilágosodás dialektikája, modernitás, idegen 
Írásom döntően Simmel A társadalmi differenciálódásról című, 1890-ben megjelent korai főmüvének harmadik fejezetére fog támaszkodni. Erről a fejezetről mondja maga Simmel, hogy az néhány évvel korábban megjelent a Zeitschrift für wissenschaftliche Philosophie címü folyóiratban. Rosszul emlékszik azonban a folyóirat nevére, amely valójában Vierteljahresschrift für wissenschaftliche Philosophie volt. Claudius Härpfer, aki alaposan megvizsgálta a fiatal Simmel publikációs tevékenységét, ezt írja:

Ha egy futó pillantást vetünk Simmel tanulmányainak formális aspektusaira, megerősödik az a benyomásunk, hogy publikációival a folyóiratok széles spektrumát szolgálta ki. Évente átlagban 12 szöveget, illetve 200 oldalt publikált, 1882 és 1910 között az összkiadás formátumában (...) összesen 1723 oldalnyi szöveget produkált (Härpfer 2010: 71-72).

A fent említett folyóirat először 1877-ben jelent meg; főszerkesztője Richard Avenarius volt, aki az alábbi sorokkal kezdte a beköszöntőjét:

Az egyik ok, amely a filozófia fejlődését nehézzé teszi, és amelyet általában kevés figyelemre méltatnak, de azért roppant hatékony, az a bizalmatlanság, amellyel a filozófiát az úgynevezett „szigorú tudományos” körökben - ha nem is általánosan, de mégis általánosabban, mint ahogy azt bevallják - fogadják. Ezt a bizalmatlanságot úgy lehet jellemezni, mint egy utolsó nagy viszszaütést, amely hirtelen véget vetett a spekulatív filozófia uralmának. Így tekintve a „filozófiával” szembeszegezett elutasító ítéletek általában csak a „spekulatív” filozófiára vonatkoznak, amely széles körökben még mindig - egykori nagyságának akaratlan elismeréseként - az általában vett „filozófiának” számít, és most egy utólagos hatással az egész újkori filozófiát belerántja a közös bajba (Avenarius 1877: 1).

Egy olyan filozófiát kellene tehát kidolgozni, amely szakít a nagy spekulatív rendszerfilozófiákkal, és ezáltal a tudományos „körök” ellenérzéseit is neutralizálni tudja. „Most már nem az a kérdés, hogy hogyan lehetséges a tudományos filozófia, hanem az, hogy hogyan lenne lehetséges a tudomány, ha nem a filozófia által" (Avenarius 1877: 18). (Ezt a megfordítást persze már Hegel is megtette, sőt talán már Kant is A természettudomány metafizikai kiinduló elvei címü müvében.) Ez az általános program Dilthey majd a neokantiánusok filozófiájára épül. Dilthey 1883-ban megjelent Bevezetés a szellemtudományokba címü könyvében írja: „A történelmi-társadalmi valóság megismerése a szellem szaktudományaiban megy végbe” (Dilthey 2004 [1883]: 117). Egy ilyen szaktudomány a szociológia is; a feladat pedig az, hogy „kifejtsük a szellemtudományok ismeretelméleti alapvetését” (Dilthey 2004 [1883]: 117). Ezt a programot aztán szívesen nevezi a „történeti ész kritikájának” is, és ennek kellene a szellemtudományok „metafizikai megalapozásának” helyébe lépnie. Aztán Heinrich Rickert Kultúratudományok és természettudományok címü kis könyvében már belebotlunk abba a problémába, hogy a tartalmi és a módszertani elválasztás nem esik feltétlenül egybe. „A természettudományos módszer jó messzire belenyúlik a kultúra területébe, és (...) nagy hiba volna azt mondani, hogy csak történelmi kultúratudományok vannak. Megfordítva azonban, a történelmi eljárásmód némiképp a természettudomány körén belül is müködik (...)" (Rickert 2006 [1899]: 201). Simmel számára fontosabb a módszertani elkülönítés, mert úgy véli, hogy a szociológia már ismert, más tudományok által is tematizált tényekkel dolgozik,

Előadásként elhangzott „A modernitás paradoxonai” című Simmel-emlékkonferencián Budapesten, 2018. december 7-én. A dolgozatot Kiss Bernadettnek ajánlom sok szeretettel. A tíz évvel ezelött közösen tartott Simmelszemináriumunkhoz kapcsolódva készült el $A$ társadalmi differenciálódásról című könyv fordítása. Köszönöm továbbá az anonim bíráló nagyon értékes megjegyzéseit. 
ezért az új tudományt csakis egy sajátos állásponton (vagyis módszeren) keresztül lehet meghatározni (Simmel 2009 [1890]: 10). De ennek a módszernek nem szabad elsiklania a tárgy fölött, ezért Simmelnek nagyon jól jönnek Avenarius viszonylag egyszerü meggondolásai. Avenarius szerint ahhoz, hogy tudományról beszélhessünk, két feltételnek kell teljesülnie. (1) Az anyagot fogalmilag kell megragadni és felosztani. „Az anyag fogalmi megragadása azáltal formálódik meg (...), hogy az alacsonyabb fogalmakból magasabbakat vezetünk le. A fogalmak ily módon megszerveződő rendszere a maga lezárását egy legfelső fogalomban találja meg, amely minden alacsonyabb fogalmat (...) önmaga alá sorol” (Avenarius 1877: 3). (2) Minden tudomány anyagát tekintve valamilyen tapasztalatra épül, és semmi másra nem is épülhet. Elhibázott tehát a „tapasztalati tudományok” ma szokásos használata, mintha ez az elnevezés kimondottan a természettudományokra vonatkozna (Avenarius 1877: 6). Simmel számára nagy valószínüséggel csak annyi volt fontos, hogy a tudományos elemzéshez megfelelő fogalmakra van szükség: és ő a legeslegelső megközelítésben két ilyen fogalmat vezet be: a „csoportot” (a „társadalmi kört”) és az „individualizációt”. Ha ezek a fölvezető gondolatok nagyjából helytállóak, akkor a korai főmű tengelyét a harmadik és az ötödik fejezet alkotja.

A harmadik fejezet alapjául szolgáló tanulmány eredetileg „Bemerkungen zu sozialethischen Problemen” címmel jelent meg (Simmel 1888). (Ez a cím nemcsak rejtélyes, de ezen túlmenően még határozatlan is: a „megjegyzések” és a „problémák” mintegy nyomatékosítják a kísérleti jelleget.) A „Sozialethik” fogalmát eredetileg egy lutheránus teológus, Alexander von Oettinger vezette be 1868-ban, Die Moralstatistik und die christliche Sittenlehre [A keresztény erkölcsi tanítás morálstatisztikája] című müvében. A feladat egy újfajta etika kidolgozása lenne, amely az „erkölcsi mozgástörvényeket” egy „induktív-numerikus tapasztalati tudomány” keretei között írja le. De ennek a programnak van még egy nagyon fontos aspektusa: az etikát nem csak tudományossá kell tenni, hanem a közösségek erkölcseinek tanulmányozására is vonatkoztatnunk kell. És így lehet statisztikai módszerekhez folyamodni. (A statisztika ekkoriban még szintén új tudomány volt.) Azt sejthetjük, hogy Simmel a „Sozialethik” kifejezést csak publikációtaktikai okokból alkalmazta, ez volt ugyanis azokban az években a szellemtudományok „tudományossá tételének” egyik fő csapásiránya. Ugyanakkor Simmel koncepciója egyáltalán nem etikai jellegű, de megragadta egy olyan probléma, amely ott áll a „Sozialethik” koncepciójának hátterében: van-e egy közösségnek etikája, és ez hogyan viszonyul az individuumok etikájához? (A „Sozialethik” kritikusai közül már sokan és nagyon korán megfogalmazták azt az ellenvetést, hogy a társadalmi csoportoknak és a társadalmi intézményeknek nem lehet etikájuk, hanem csak a konkrét emberek lehetnek az etika „szubjektumai”.) Simmel kérdése az volt, hogy az individuum hogyan viszonyul a közösséghez, pontosabban ezt a kérdést megpróbálta felülemelni egy triviális megközelítésen. S ezt azáltal éri el, hogy a modernitás tapasztalatát helyezi a középpontba. David P. Frisby szerint Simmel a modernség első nagy teoretikusa: „Ha a kortársak ítéletére figyelünk, akkor azok gazdagon alátámasztják azt a tézist, hogy Simmel rendelkezett azzal a képességgel, hogy a modernség alapvető tapasztalatait oly módon ragadja meg, amire csak nagyon kevés kortársa volt képes” (Frisby 1984: 16). A Simmel halálának századik évfordulójára megjelent cikkében Thomas Assheuer ezt írta: „Simmel valóban a leírás zsenije volt. Abszolút hallással regisztrálta a »társadalmi test « legkisebb vibrációit is: írt a divatról, az alpesi turizmusról, az ékszer pszichológiájáról és Isten személyiségéről - és mindenről zseniálisan" (Assheuer 2018: 19). 
Simmel nagy valószínűséggel már az eredeti dolgozat elkészítésekor is ismerte Ferdinand Tönnies Közösség és társadalom címü 1887-ben megjelent könyvét. Persze ebben egészen biztosak nem lehetünk, mivel a megjelenés dátumai túl közel esnek egymáshoz, és Simmel maga kimondottan nem hivatkozik a könyvre. Ugyanakkor tudjuk, hogy a könyv már a megjelenésekor nagy feltünést keltett. A kor egyik legelismertebb filozófusa, Friedrich Paulsen írt róla recenziót:

Az összélet történelmi fejlődését a szerző szerint a közösségtől a társadalom felé tartó mozgásként lehet leírni. A történelmi ősforma a vérrokonság által egyesített törzs, a klán, a végső forma pedig, amely felé a civilizáció tendál, a világbirodalom, amely lényegében a nagyvárosokban áll fenn, amelyekben mindenki idegen mindenki más számára, és teljes tudatossággal önmagát tételezi abszolútként, míg másokkal csak véletlenszerü viszonyban áll, a kereskedelmen, a szerződéseken, a konkurencián és a társiasságon keresztül (Paulsen 1888: 113).

Tönnies könyve legalább két gondolatával nagy hatást gyakorolhatott a fiatal Simmelre. Egyrészt a közösségből a társadalomba való átmenet nyilvánvalóan a modernitás kialakulásaként értelmezhető. „A társadalom (...) a nyilvánosság, a világ. (...) A társadalomban idegen területre lépünk” (Tönnies 2004 [1887]: 9). A „nyilvánosság” ekkor még szokatlan kifejezés (habár a „publikum” szó már a 18. század óta ismert volt), a jelentése itt valószínűleg annyi, hogy ami túl van a magánélet (a család, a privát-személyes kapcsolatok) világán. A nyilvánosságban mindannyian idegenként mozgunk; a modern világ annyit jelent, hogy az életünk idegen emberek között zajlik. Ha igaz ezért, hogy a megszülető szociológia a modernitással foglalkozik, akkor ebben centrális szerepe van az idegenségnek. Simmel erről majd ezt írja: „Az idegenlét (...) azt jelenti, hogy a távoli közel van. Az idegenlét természetesen egy pozitív megjelölés, egy különös kölcsönhatási forma; a Szíriusz lakói tulajdonképpen nem idegenek a számunkra" (Simmel 1987 [1908]: 63). Az idegenség az, amikor a távoli közel lép hozzánk. Vagyis olyan emberekkel kerülünk kapcsolatba, akikhez az égvilágon semmi közünk sincs. (Az idegen és az idegenség tapasztalatának centrális jelentőségére a modernitás elméletén belül már Felkai Gábor is rámutatott, bár ezt még nem vonatkoztatta magára Tönniesre, lásd: Felkai 2006: 301-305.) A fenti két mondat ugyanakkor egymás komplementereként is olvasható: az egyik oldalon áll a társadalom mint meghatározott szféra, vagyis a társadalom nem a szociális realitás egésze. A másik oldalon áll az individualitás, amely magát szükségképpen idegennek érzi. Vagy egy kicsit másképp: „Az emberi társadalmat egymástól független személyek puszta egymásmellettiségének tekintjük" (Tönnies 2004 [1887]: 10). Ez a puszta egymásmellettiség az együttélés érzelmi hidegségéhez vezet. Így jön létre a kidolgozandó szociológia két pólusa: az egyik oldalon áll a társadalmiság, a másik oldalon az individuum belső hogyléte. Még talán azt is megkockáztathatnánk, hogy a modernitást leíró diszciplína igazából nem is a szociológia, hanem a szociálpszichológia. Bár ezzel a kifejezéssel némileg előrefutunk: a „szociálpszichológia” könyvek címében elöször 1908-ban bukkant föl. ${ }^{2}$ És még ugyanebben az évben Simmel írt is egy cikket erről a

2 Lásd Edward A. Ross: Social Psychology (An Outline and Source Book, The Macmillan Company, 1908) és William McDougall: Introduction to Social Psychology (London, Methuen, 1908). Az előbbi szerző szociológus, az utóbbi pszichológus volt. 
kifejezésről. „Az individuum pszichológiájával szembeállították a »társadalom « (a tömegek, a csoportok, a nemzetek, a korok) pszichológiáját, mint lényegét és hordozóját tekintve egységes képződményt” (Simmel 1908: 285). Simmel egyáltalán nem örül ennek a fejleménynek, de a vele való szembeszálláshoz nem elég, ha kimondjuk, hogy a lelki folyamatok csak az individuumban játszódhatnak le és sehol máshol. Valahogy meg kellene értenünk e kifejezés megszületésének társadalmi hátterét is. Simmel nem hagy kétséget afelöl, hogy ez csak metaforikus beszédmód lehet. Ha a lélek azt jelenti, ami valamit élővé-elevenné tesz, akkor ezt átvitt értelemben a társadalmi intézmények és a kulturális szférák müködésére is vonatkoztathatjuk. „S mert ezeknek a maguk egészében kell hogy legyen egy hordozójuk és előállítójuk, ami nem lehet az egyes ember, ezért csak az marad vissza, hogy ez a szubjektum a társadalom, amely az egyes emberekből áll, de ugyanakkor túl is van az egyes embereken” (Simmel 1908: 285). Ennek a beszédmódnak van messzebbre visszanyúló tradíciója: „Ebből a nézőpontból kiindulva beszéltek [már korábban is] a néplélekről, a társadalom tudatáról vagy a kor szelleméről, mint reális és produktív hatalomról” (Simmel 1908: 285). (Simmel azokkal az érvekkel bírálja a szociálpszichológia terminusát, amelyek alapján már korábban nagy valószínüséggel leszámolt a Sozialethik fogalmával is.³) Így az 1890-es könyv alcímében Simmel szociológiai és pszichológiai vizsgálódásokról beszél; természetesen fontos, hogy elsőnek a szociológiát említi, a pszichológia mintegy ezen belül helyezkedik el.

A Tönnies által két szélső pólusként rögzített közösségszerveződés aligha ad kimerítő leírást, inkább maga is sematikus megközelítésnek tünik. Ugyanakkor nagy hatással lehetett Simmelre, ami még az 1908-as Szociológia című könyv néhány megfogalmazásában is jól érezhető. „A korábbi állapotok szoros és szigorú kötelékei, amelyekben a társadalmi csoport mint egész, illetve annak központi hatalma az egyes ember tevékenységeit és mulasztásait a legkülönbözőbb irányokban szabályozza, a maga szabályait egyre inkább az általánosság szükségszerü érdekeire korlátozza (...)” (Simmel 1908: 325). Simmelnél a társadalmi realitás a társadalmi szerveződés különböző formáiból épül fel, és ezeket társadalmi köröknek vagy csoportoknak nevezi (Simmel 2009 [1890]: 33). A társadalmi szerveződéseket Simmel az individuumok „együttélésének”, „egységesedésének” és „kölcsönös egymásra hatásának” formáiként vezeti be (Simmel 1908: 32). És ezeket a formákat elsődlegesen nem a történelmi körülmények határozzák meg, hanem a puszta kvantitatív összefüggések.

A mindennapi tapasztalatokból kiindulva eleve el kell ismernünk, hogy egy csoport egy bizonyos nagyságtól kezdve a maga fönntartásához és előmozdításához olyan szabályokat, formákat és szerveket alakít ki, amelyekre korábban nem volt szüksége; és hogy másrészt a szorosabb körök olyan minőségeket mutatnak fel, amelyek a számbeli kibővítésüknél szükségképpen veszendőbe mennek (Simmel 1908: 32).

Ebből kiindulva belátható, hogy vannak olyan formák, amelyek „tartalmi és egyéb életformákból kiindulva szükségesek és lehetségesek, [de] csak az elemek numerikus határán innen vagy túl valósíthatók meg” (Simmel: 1908: 33). Simmelnél a modern élet azt jelenti, hogy a társadalom szerveződésében egyre nagyobb szerepet kapnak a nagycsoportok:

3 Ha egy pillantást vetünk a Hunyady György által szerkesztett Szociálpszichológia című kötetre, akkor nagyon érdekes tanulmányokkal találkozhatunk ugyan, de a diszciplína egységessége még csak körvonalaiban sem látszik. A megjelenő témák többek között: attribúcióelmélet (milyen okokat tulajdonítunk a mások viselkedésének), az attitűdök és a viszonyulások következetessége, a sztereotípiák és a nézetek rendszerének szerveződése (Hunyady 1983). 
Az emberek igen nagy száma csak határozott munkamegosztás esetében alkothat egységet; és nemcsak a gazdasági technika kézenfekvő okainál fogva, hanem mert ez hozza létre az egymásba való átnyúlást és az egymásra való ráutaltságot, amely számos közbeeső láncszemen keresztül mindenkit mindenkivel összeköt (Simmel 1908: 33).

A modernségre jellemző társadalmi szerveződésben így egyre nagyobb szerepet kap a munkamegosztás és a specializálódás. Az 1890-es könyv így lesz a modernizáció elmélete.

Ebbe az összefüggésbe illeszkedik Simmelnél a „szocializmus” akkoriban népszerűvé váló eszméjének bírálata is: „Véleményem szerint meg lehet állapítani, hogy a teljesen vagy megközelítőleg szocialista rendszereket csak egész kis körökben lehetett bevezetni, a nagyobb körökben azonban rendre kudarcot vallottak” (Simmel: 1908: 32). A tanulmány eredeti változatában pedig egy még alapvetőbb kritikát olvashatunk: „A különbségeknek a szocializmus által célként kitűzött megszüntetése minden meghatározott minőség megszüntetésének előzetes foka, úgy, ahogy azt a nihilista pesszimizmus megköveteli” (Simmel 1888: 48).

\section{II.}

A társadalmi differenciálódásról című könyv alaptanulmánya abból a feltevésből indul ki, hogy van két csoportunk, amelyek mind a „karakterisztikus tulajdonságokat”, mind a „kölcsönös lelkületet" tekintve a lehető legélesebben különböznek egymástól, vagy metaforikusan azt is mondhatnánk, hogy a lehető legmesszebb állnak egymástól. És akkor elindulnak a modernitás irányába mutató társadalmi folyamatok, amelyek alapstruktúráját a társadalmi differenciálódás jelöli ki; s ennek következtében, illetve során, a két csoport tagjai egyre hasonlóbbak lesznek egymáshoz. Ezt a megfigyelést, amelyet Simmel alapvető társadalmi törvénynek nevez, a következőképpen is megfogalmazza: „A differenciálódás (...) feloldja a közelálló emberekhez füződő szoros köteléket, hogy cserébe új (reális és ideális) kötelékeket teremtsen a távol álló emberekhez" (Simmel 2009 [1890]: 53). (Most tekintsünk el gyorsan az idézet zavarba ejtő folytatásától: „hasonló [összefüggést] figyelhetünk meg az állat- és növényvilágban”, Simmel 2009 [1890]: 53.) Nincs tehát igaza Tönniesnek: a modernség kialakulását nem lehet elementáris közösségvesztésként diagnosztizálni. „A társadalomban mindenki egyedül van, s állandó feszültség van közte és a többiek között” (Tönnies 004 [1887]: 57). A modernség Simmel szerint nem csökkenti az összetartozást, az egymásrautaltságot, hanem csak új formát ad neki. Tönnies diagnózisa nem más, mint egy elméletileg valamelyest alátámasztott populáris panaszkodás. Abban Simmelnek kétségtelenül igaza van, hogy így sikerül megmagyarázni a világpolgárság kialakulását. „A növekvő megformálódás [a társadalmi differenciálódás] elindítja az idegenekhez való közeledést az eredeti, homogén csoporton túlmutató egyenlőség bázisán" (Simmel 2009 [1890]: 54). Nem a modern viszonyok válnak idegenné, hanem a modern világ teszi lehetővé az idegenhez való közeledést, az idegen álláspontjának asszimilálását. A modernség paradigmatikus helyévé így a nagyváros válik. (Simmelt nemcsak és nem is elsősorban a nagyváros berendezkedése, hanem az emberi lélekre kifejtett hatása érdekli. De erre ezen a helyen nem tudok kitérni.) Közelebbről tekintve ebben a fejezetben alapvetően nem is a csoport és az individualizáció kapcsolatáról volt szó (az individualizáció ugyanis nem a differenciálódás eredményeként, hanem a fonákjaként jelenik meg). Inkább a csoportdinamika alapvető természetét láthatjuk magunk előtt: azt, ahogy a differenciálódás a nivellálódásba csap át; méghozzá egy sajátos dialektikának köszönhetően. Simmel korai főműve A felvilágosodás dialektikájának egyik legfontosabb előzménye. 
A könyv ötödik fejezete nem egyszerüen kiegészíti a korábban megjelent tanulmányt (a harmadik fejezetet), hanem lényegesen korrigálja is annak szemléletmódját. Itt már valóban a csoport és az individualizáció kapcsolatáról van szó. A társadalmi differenciálódás most a csoportok számának növekedését jelenti. Ezt Simmel így fogalmazza meg: „Mármost a különböző körök száma, amelyen belül az egyesek elhelyezkednek, a kultúra egyik leglényegesebb fokmérője” (Simmel 2009 [1890]: 105). (A „körök”-et itt Simmel egy kvázi geometriai szemléltetés érdekében használja a „csoport” fogalma helyett.) A „kultúra” szó (amelynek elötérbe állítása Rickertre vezethető vissza) talán zavarba ejtő lehet: a kultúra Simmelnél az élet, vagy ha tetszik, a történelem fogalma. Amikor Simmel filozófiai, vallási vagy müvészeti kultúráról beszél, akkor azon nem a metafizikai rendszerek, a vallási dogmák vagy a konkrét müalkotások ismeretét érti, hanem egyfajta intellektuális nyitottságot, az élet vallási normákat követő berendezését vagy művészi értékekre épülő megformáltságát (Simmel 1919: 4). Így a mondatot egyszerűen értelmezhetjük a történelmi fejlettség meghatározásaként is. A modern ember a legkülönbözőbb körökbe tartozhat: a családjába, aztán a házasságkötéssel a felesége családjába, a városába, a foglalkozásába stb. (Simmel 2009 [1890]: 105). Ezek után két eset lehetséges: a körök vagy koncentrikusak, vagy metszik egymást. Akkor beszélhetünk koncentrikus körökröl, ha minden kör az őt megelőző kör kiterjesztése, mint például Arisztotelész Politikájában vagy Hegel Jogfilozófiájában. De előfordulhat az is, hogy a körök metszik egymást: ez akkor következik be, ha az egyik körben való részvételből nem következtethetünk a másikban való részvételre. Az individualizáció azt jelenti, hogy az ember különböző, egymást metsző körökbe tartozik. Minél több ilyen körbe tartozunk, annál individuálisabbak leszünk. A képet még az is tarkítja, hogy az ember a különbözö körökben különböző pozíciókat foglalhat el:

Itt csak arra szeretnék utalni, hogy az individualizáció lehetősége már azáltal is a végtelenbe tart, hogy ugyanaz a személy a különböző körökben, amelyekhez egyidejüleg tartozik, különböző viszonylagos pozíciókat foglalhat el. Mert minden újabb összezáródás ugyanabból a nézőpontból azonnal létrehoz valamiféle egyenlőtlenséget, egy differenciálódást a vezetők és a vezetettek között (Simmel 209: 107).

$\mathrm{Az}$ individualizáció lehetősége tehát két ok miatt is végtelen: egyrészt a körök száma, másrészt a körökön belüli pozíciók száma miatt.

Ezen a két úton próbálta Simmel a szociológiát tudományossá tenni. És ezzel eljutottunk egy fontos szociológiatörténeti feszültség forrásához is: a modernitás (az individualizáció) elmélete sajátos feszültségben áll a társadalom szerkezetének (a társadalmi egyenlőtlenségek) leírásával. (Legalábbis, ha az Über sociale Differenzierung címü könyvre összpontosítunk.) Simmelt nem a társadalom szerkezete, hanem a társadalom modernizációja érdekelte; nem az idegen helyzetére, hanem az idegen asszimilációjának esélyeire és lehetőségeire volt kíváncsi. Ezek a szempontok és megközelítések adják aktualitását halálának századik évfordulóján. 


\section{Hivatkozott irodalom}

Assheuer, Thomas (2018): „Wir alle sind Fragmente”. Die Zeit (szeptember 19.).

Avenarius, Richard (1877): Zur Einführung. Vierteljahresschrift für wissenschaftliche Philosophie 1(1): 1-2. Interneten: https://gallica.bnf.fr/ark:/12148/bpt6k94128f/f10.item.

Deutsch, Morton (1980): A csoport kialakulása. In Csoportlélektan. Pataki Ferenc (szerk.). Budapest: Gondolat.

Dilthey, Wilhelm (2004 [1883]): A történelmi világ felépitése a szellemtudományokban. Budapest: Gondolat.

Felkai Gábor (2006): A német szociológia története, I. kötet. Budapest: Századvég.

Frisby, David P. (1984): Georg Simmels Theorie der Moderne. In Georg Simmel und die Moderne. Heinz-Jürgen Dahme és Ottheim Rammstedt (szerk.). Frankfurt am Main: Suhrkamp, 9-79.

Härpfer, Claudius (2012): Georg Simmel und die Entstehung der Soziologie in Deutschland. Eine netzwerksoziologische Studie. Berlin: Springer VS.

Hunyady György (szerk.) (1983): Szociálpszichológia. Budapest: Gondolat.

Paulsen, Friedrich (1888): Ferdinand Tönnies: Gemeinschaft und Gesellschaft. Vierteljahresschrift für wissenschaftliche Philosophie 12(1): 111-119. Interneten: https://gallica.bnf.fr/ark:/12148/bpt6k941393/f1.item.

Rickert, Heinrich (2006 [1899]): Kultúratudományok és természettudományok. In Történetelmélet, II. kötet. Gyurgyák János és Kisantal Tamás (szerk.). Budapest: Osiris.

Simmel, Georg (1888): Bemerkungen zu sozialethischen Problemen. Vierteljahresschrift für wissenschaftliche Philosophie 12(1): 32-49. Interneten: https://gallica.bnf.fr/ark:/12148/bpt6k941393/f1.item.

Simmel, Georg (1908): Soziologie. Untersuchungen über die Formen der Vergemeinschaftung. Berlin: Duncker und Humblot.

Simmel, Georg (1919): Philosophische Kultur. Stuttgart: Alfred Kröner.

Simmel, Georg (1987 [1908]): Der Fremde. In uö Das individuelle Gesetz. Philosophische Exkurse. Michael Landmann (szerk.). Frankfurt am Main: Suhrkamp.

Simmel, Georg (2009 [1890]): A társadalmi differenciálódásról. Szociológiai és pszichológiai vizsgálódások. Budapest: Gondolat.

Tönnies, Ferdinand (2004 [1887]): Közösség és társadalom. Budapest: Gondolat.

\section{Ueıss János}

Filozófus, egyetemi tanár, PTE BTK Filozófia Tanszék (Pécs) 